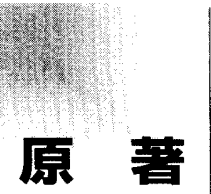

2001 年 2 月19日

2001 年 7 論文受理

Code No. 523

\section{逐次近似再構成法における分解能・統計雑音 および最適逐次回数の基礎的検討}

\author{
大西英雄・飯田忠行 $\cdot$ 松尾 悟1)
}

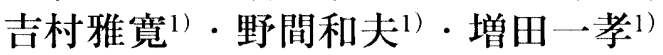

広島県立保健福祉大学保健福祉学部放射線学科

1 ) 滋賀医科大学附属病院放射線部

\section{はじめに}

近年, single photon emission computed tomography (SPECT) 装置の進歩は日覚ましく，コンピュー夕技術 の進歩も急速に進み，ダウンサイジングに始まり商性 能で低価格なデータ処理装置が臨床現場にリリースさ れてきたＳSPECTで使われるほとんどの画像再構成法
は, XCTと同様に重畳積分法もしくはフーリエ変換法 1)よ゙の解析的手法であった。特に, SPECTでは $\gamma$ 線 の吸收, 散乱等の物理特性とデー夕自体の確率的要素 (統計的)があり，それらの因子が複雑に絡み合って画 質に大きく影響し，画質自体に統計的(確率的)要素が 多く含まれる。このようなSPECT画像固有の特性を画

\title{
Fundamental Evaluation of the ML-EM Reconstruction Algorithm for SPECT Images: Resolution, Noise, and Optimal Iterations
}

\author{
HIDEO OHNISHI, TADAYUKI IIDA, SATORU MATSUO, "TETSUO KIDA,") \\ MASAHIRO YOSHIMURA, ' KAZUO NOMA, ") and KAZUTAKA MASUDA") \\ Department of Radiological Sciences, Hiroshima Prefectural College of Health Sciences Faculty \\ of Health Sciences \\ 1 ) Department of Radiology, Shiga University of Medical Sciences \\ Received Feb. 19, 2001; Revision accepted July 13, 2001; Code No. 523
}

\section{Summary}

We evaluated the optimal number of iterations on maximum likelihood-expectation maximization (MLEM) reconstruction algorithm in SPECT images using four methods: full width at half maximum (FWHM), statistical noise, edge recovery of image (recovery coefficient; RC), and normalized mean squared error (NMSE). We acquired SPECT images using $99 \mathrm{~m}-\mathrm{Tc}$ as a signal source for three phantoms: a line source phantom, uniform cylinder, and hot rod phantom. The line source phantom was used to measure reconstructed image resolution; the uniform cylinder phantom was used to evaluate statistical noise and image recovery; and the hot rod phantom was used to evaluate the NMSE method. We varied acquisition time as follows: $300 \mathrm{sec} / \mathrm{step}, 30 \mathrm{sec} / \mathrm{step}$, and $5 \mathrm{sec} / \mathrm{step}$, and numbers of iterations of ten times and more. Statistical noise converged early at 50 iterations for acquisition time for $300 \mathrm{sec} / \mathrm{step}$. The RC value neared 1.0 for $300 \mathrm{sec} / \mathrm{step}$, but remained at $0.7 \mathrm{for} 30 \mathrm{sec} / \mathrm{step}$ and $5 \mathrm{sec} / \mathrm{step}$. The optimal number of iterations was 50 for images obtained with the high frequency ingredient with $30 \mathrm{sec} / \mathrm{step}$ and 30 for images obtained with low frequency. The number of iterations should be changed according to acquisition time and the frequency ingredient contained in images.

Key words: Maximum likelihood-expectation maximization (ML-EM), Single photon emission computed tomography (SPECT), Normalized mean squared error (NMSE), Iteration

別刷資料請求先：干723-0053 妄鳰県三原市学園町1-1

広島県立保健福社大学: 保健福祉学部 大西英雄 宛 
像再棈成の逐次近似法に組み迄んで，画質を同上させ ようとする研究2,3急速に進められている。その代 表的な逐次近似画像再構成法に最尤推定による期街值 最大化 (maximum likelihood-expectation maximization: ML-EM) 法 ${ }^{4-6)}$ がある。これは光子・の発生確率がポア ソン分们を早し，それをモデル化することで検出器の

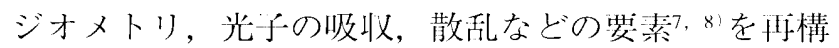
成のなかに組み入れ補止することができる再棈成法で ある。この方法は膨大な訃算処理時間が必要であった が，近年の計算機能Jの们上により-踓脚光を浴びる ようになった。またML-EM法の変法である ordered subsets expectation maximization (OSEM) ${ }^{9}$ (10)のような畐 速アルゴニズムの開発により，臨床現場で十分使对で きる状況になっている，以前からML-EM法での基本 的なパラメータである遂次回数に関しては, シュミレ 一ション的解析 $\left.{ }^{-1}, 3\right)$ が盛んに行われているが，臨休デ 一タに沿った解析はあまり行われていない。そこで, われわれはML-EM画像侢構成法を为いた基礎的な検 副として收集㭙間と逐次回数 (iteration)の関係を分解 能, 統計雑音, 画像エッジ部の回往 (recovery coefficient: RC) およびnormalized mean squared error (NMSE) 法12)等を用いて最適な逐次回数を定星的に解 析したので報㸃する。

\section{1. 方 法}

\section{1-1実験方法}

使用するSPECT装置は，3検出器型GCA-9300-A（株 式会社束芝製)，デー夕処理装置はGMS-5500UI，使 用核種は99m Tcを使用した。コリメータは低エネルギ 一用品分解能 (LEHR) を使用し, LEHRコリメータの

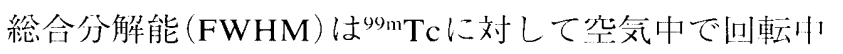
心 $(13.2 \mathrm{~cm})$ において $9 \mathrm{~mm}$ である。

分解能評価用ファントムとしては, 直径 $20 \mathrm{~cm} \phi$, 長 さ $20 \mathrm{~cm}$ の忺柱ファントム：外容器 (SPECT性能部狮フ アントム：東芝社製）を用い，5本からなる $1 \mathrm{~mm} \phi$ の線 線源 (分解能測定用内容器)を前述した外谷器に装着す る。線線源には $37 \mathrm{MBq} / \mathrm{cc}$ の ${ }^{99 \mathrm{~m}} \mathrm{Tc}$ を封入し, 収集条件 は128×128マトリクス $(1 \mathrm{pixel}=0.32 \mathrm{~cm}), 30 \mathrm{sec} / \mathrm{step}$,

30step，120度で収集を行った．ML-EM画像再構成法 の逐次回数を $1,5,10,15,20,30,40$ 方よび50と 変化させて画像再構成を行った。

統計雑音の評価, 画像エッジ部の回復評洒および NMSE法の諨価で使用したファントムは，均一性およ び陽性画像用として付属の陽性用ファントム内容器を 前述した外容器に装着し, ${ }^{99 \mathrm{~m}} \mathrm{Tc}$ を $740 \mathrm{MBq}$ 封入した。 收集条件は，128×128マトリクス，30step，120度収 集で行った，収集時閒を5，30および $300 \mathrm{sec} / \mathrm{step}$ 変

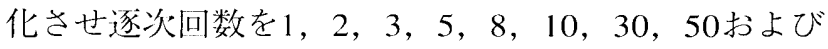

80 と変化させて画像再構成を行った。また，再構成処 理に扮いては前処理フィル夕は用いなかった。両収集 とも，吸収補正抢よび政乱線補止は行っていない。な お， $300 \mathrm{sec} / \mathrm{step}$ 收集時には投影デー夕に対し全収集中 心時間で半減期補正処理在行った。

\section{1-2 評価方法}

\section{1-2-1 分解能評価}

分解能哜価用ファントムを汌て，ファントム中心 の断而像でゆ心部(on-axis) と問辺部 (off-axis)のそれ ぞれのtangential 问, radial方向のプロファイル曲線 を作成し半值幅 (FWHM) 抢よび1/10值幅(FWTM)を 算出する。近傍の 2 断面(ファントム中心から上下 $3.2 \mathrm{~cm}$ の位㯰) も同様に処理しFWHM，FWTMをそれ

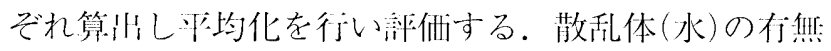
も同時に評狮古る。

\section{1-2-2 統計雑音の評価}

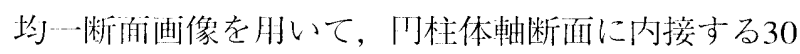
$\times 30$ pixelの知形ROI（関心領域：以下，ROI）を陪走し ROI人均均カウント (average), 標準偏差(SD) およ びその比から以下のroot mean square uncertainty （RMSU）を算出して統計雑音の評価を行う。

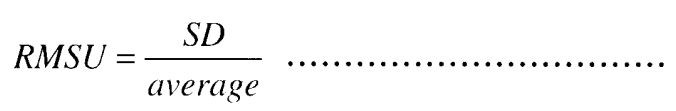

近傍の 2 断面(上下 $3.2 \mathrm{~cm}$ の位㯰)も同様に処理し RMSU值の半均化を行いRMSU值が一定值になる逐次

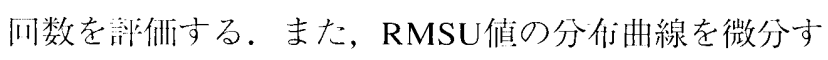
ることによりその変化 (以卜， $\Delta$ RMSU) 求め数值の 收束性をを評晌する。な抢，吸収の影響で性部の SPECT值の低下を補うためにROIの範井を大きく設 尘市る。

\section{1-2-3 画像エッジ部の回復評価}

フィルタ逆投影法(FBP)で処理した均一断面面像の プロファイル曲線の\%ちトがり部分(エッジ)の傾き (gradient) と逐次近似画像再棈成で処理した均一断闻 像のプロファイル曲線のエッジの傾きとの比をrecovery coefficient $(\mathrm{RC})$ と定義して式 $(2)$ より算出し評㑛拉 る.

$$
R C=\frac{\text { Gradient of } M L-E M \text { process image }}{\text { Gradient of } F B P \text { process image }} \ldots
$$

gradient of ML-EM process image :

ML-EM画像再構成処理画像での傾き

gradient of FBP process image :

FBP再像再構成処理曲像での傾き 
なお，FBP法では前処理フィルタを使用せず再構成フ イルタにramp関数を用い, 近傍の 3 断面(上下 $3.2 \mathrm{~cm}$ の位置) も同様に処理し平均化を行う.

\section{1-2-4 NMSE法での評価}

評価方法 1-2-3 の統計雑音で300 sec/step収集時での $\Delta \mathrm{RMSU}$ 值がほぼ一定になった逐次回数を基準画像の 逐次回数 $(\mathrm{It}=50)$ として, $5 \mathrm{sec} / \mathrm{step}, 30 \mathrm{sec} / \mathrm{step}$ おび $300 \mathrm{sec} / \mathrm{step}$ で収集したデータの逐次回数を変化させた ときの画像を処理画像とする. それぞれの処理画像に おけるNMSE值を式(3)から算出し，その值が最小と なる逐次回数を最適な逐次回数とする。なお，陽性断 面画像を高周波成分で多く含む画像, 均一断面画像を 低周波成分を多く含む画像であると定義する。

$$
N M S E=\frac{\sum_{i=0}^{x} \sum_{j=0}^{y}(g(i, j)-f(i, j))^{2}}{\sum_{i=0}^{x} \sum_{j=0}^{y} f(i, j)^{2}} \ldots \ldots \ldots \ldots \ldots \ldots
$$

$f(i, j)$ : 基準画像

$g(i, j):$ 処理画像

\section{2. 結 果}

収集時間 $(5 \mathrm{sec} / \mathrm{step}, 30 \mathrm{sec} / \mathrm{step}, 300 \mathrm{sec} / \mathrm{step})$ での 逐次回数 $(1,3,5,8,10,30,50)$ および陽性断面 画像および均一断面画像をFig. 1 に示す。収集時間が 短くなるにつれて低周波成分を多く含む均一断面画像 のざらつきが目立ち, 逐次回数を増加させることによ りその傾向が増加した。高周波成分を多く含む陽性断 面画像でも同様な現象が生じているが，均一断面画像 に比較して長時間収集の場合においてはざらつきが目 立たなかった。吸収補正を行っていないため均一断面 画像で中心部のカウント低下が生じた。

\section{2-1 分解能評価}

横軸に逐次回数と縦軸にFWHMをとり，散乱体の 有無および位置による分解能の変化をFig. 2に示す. FWHMおよびFWTMの值は, 逐次回数が10以上では 散乱体の有無および位置の変化にかかわらず同じ值を 示した. 散乱体の有無におけるFWTMでは顕著な差が みられた。

\section{2-2 統計雑音の評価}

ROI内の平均値, SD值, RMSU值および $\Delta \mathrm{RMSU}$ 值 をFig. 3に示す。横軸に逐次回数を縦軸にそれぞれ評 価する值をとっている. 平均値 (Fig. 3a)では逐次回数 10 以上で值の変動はみられないが，SD值のグラフ

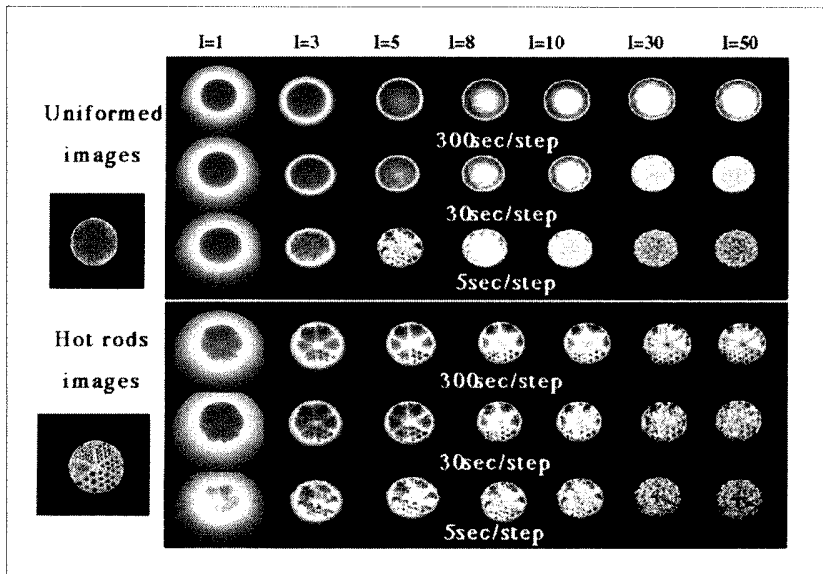

Fig. 1 Comparison of acquisition time and iteration in the uniform cylinder and hot rod phantom SPECT images.

(Fig. 3b)では逐次回数が増加するにしたがって值は増 加している。これを総合的に統計雑音の指標である RMSU值掞よび $\Delta$ RMSU值 (Fig.3c, d) で評価すると， 短時間収集時 $(5 \mathrm{sec} / \mathrm{step})$ では逐次回数を増加するごと にRMSU值も増加しているが，逐次回数50以上であれ ば長時間収集 $(300 \mathrm{sec} / \mathrm{step})$ で一定值に収束し，Fig. 3d においてほほ平坦な分布となった。この結果を踏まえ て逐次回数50をNMSE法での基準画像 $(300 \mathrm{step} / \mathrm{sec}) の$ 逐次回数とした．特にFig. $3 \mathrm{~d} よ り 30 \mathrm{sec} / \mathrm{step}, 5 \mathrm{sec} / \mathrm{step}$ において $\Delta$ RMSU值は下降線をたどり収束しなかっ た。

\section{2-3 画像エッジ部の回復評価}

縦軸にRC值を横軸に逐次回数をプロットしたエッ ジ部の回復評価の結果をFig. 4に示す. RC值は, $300 \mathrm{sec} / \mathrm{step}$ 収集で逐次回数を増加させると，逐次回数 が80の場合はRC $=0.975$ となり $\mathrm{RC} の$ 值が1.0に近づい た。しかし，その他の収集 $(5 \mathrm{sec} / \mathrm{setp}, 30 \mathrm{sec} / \mathrm{step}) に$ おいてはRC $=0.7$ で一定となり逐次回数を増加させて も1.0には近づかなかった。

\section{2-4 NMSE法}

縦軸にNMSE值を横軸に逐次回数をとり収集時間の 差 $5 \mathrm{sec} / \mathrm{step}, 30 \mathrm{sec} / \mathrm{step} お よ ひ ゙ 300 \mathrm{sec} / \mathrm{step}$ にる均一断 面画像と陽性断面画像のNMSE值をFig. 5に示す。両 分布ともに下に凸な分布を呈し，分布の最小值が存在 した. NMSE值が最小となる逐次回数は，均一断面画 像では $5 \mathrm{sec} / \mathrm{step}, 30 \mathrm{sec} / \mathrm{step}$ と同じ逐次回数 $10 か ゙$ 最適 な值となった。陽性断面画像ではNMSE值が最小とな る逐次回数は $5 \mathrm{sec} / \mathrm{step}$ で $10,30 \mathrm{sec} / \mathrm{step} て ゙ 30$ となり， 収集時間が大きくなるにつれてその值は増加した。 
(a)

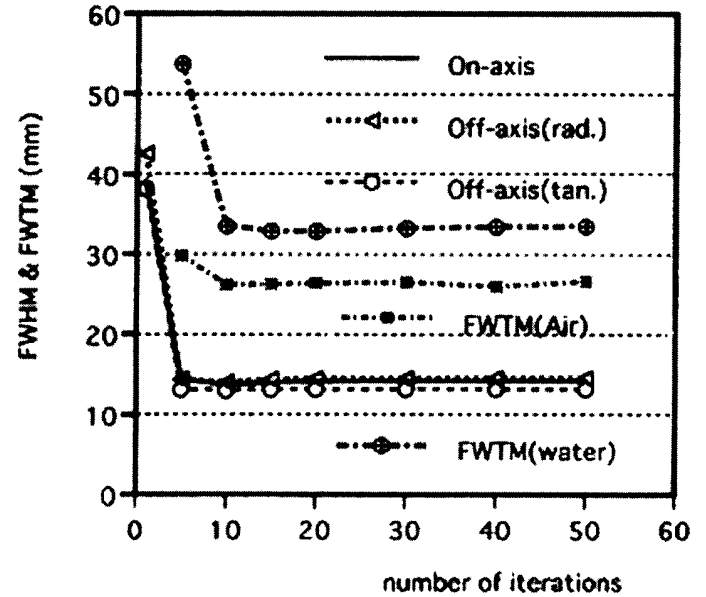

(b)

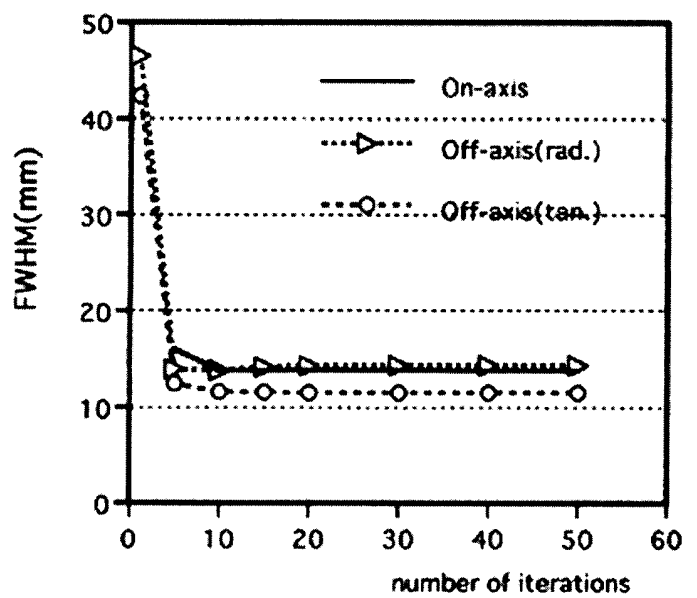

Fig. 2 (a)FWHM measurements for the line source in air and FWHM measurements for the line source on the axis in air and water.

(b) FWHM measurements for the line source in water.

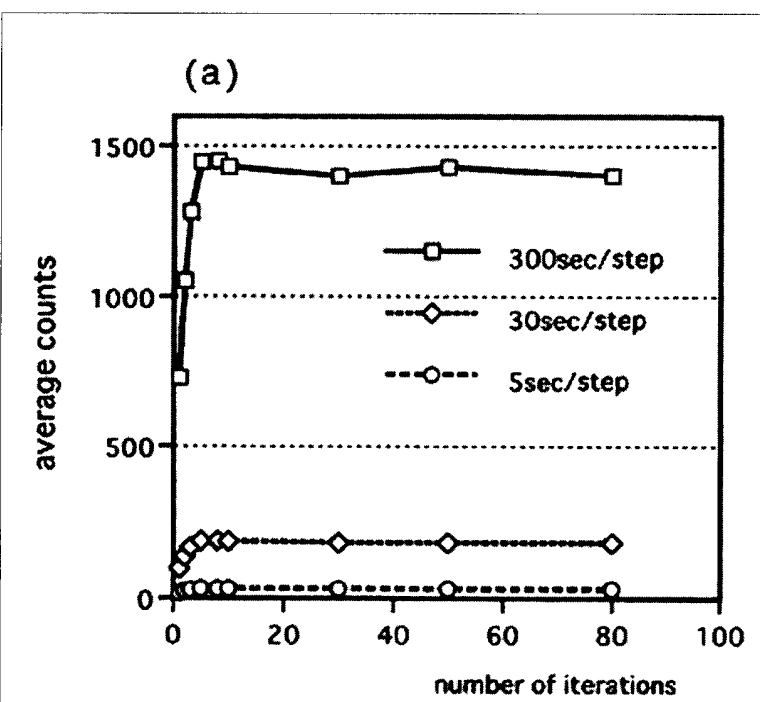

(c)

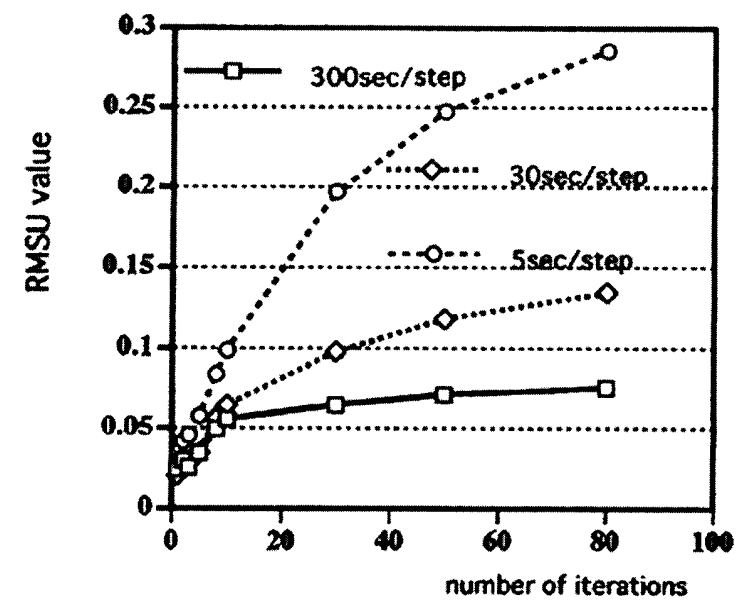

(b)

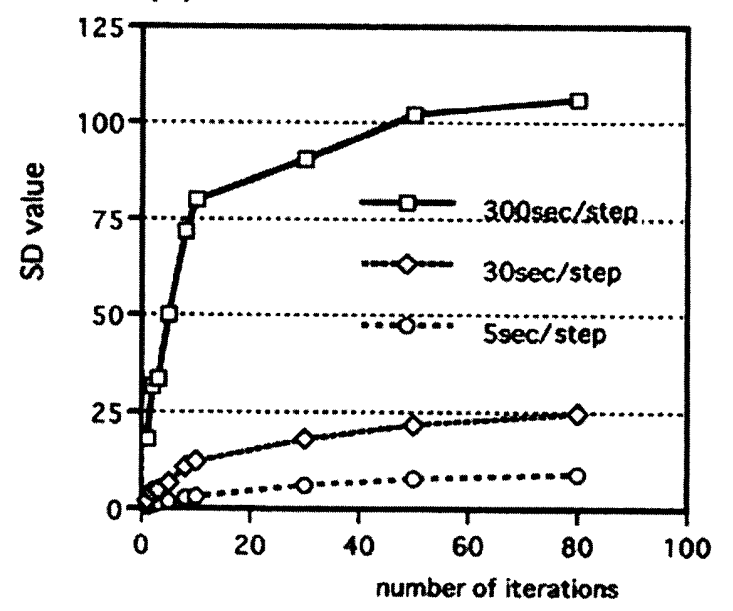

(d)

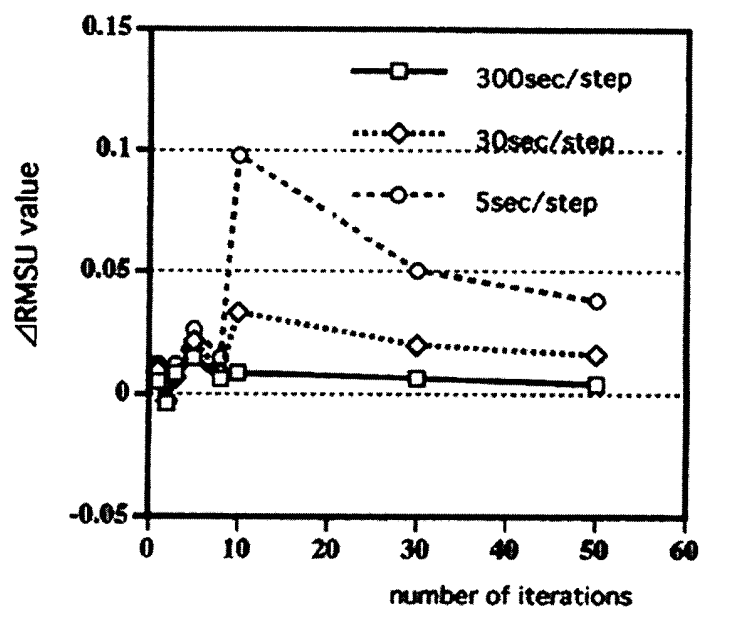

Fig. 3 Measurements for uniform cylinder SPECT images in the ROI counts.

(a) average counts, (b) SD, (c) RMSU values, (d) variation of RMSU values. 


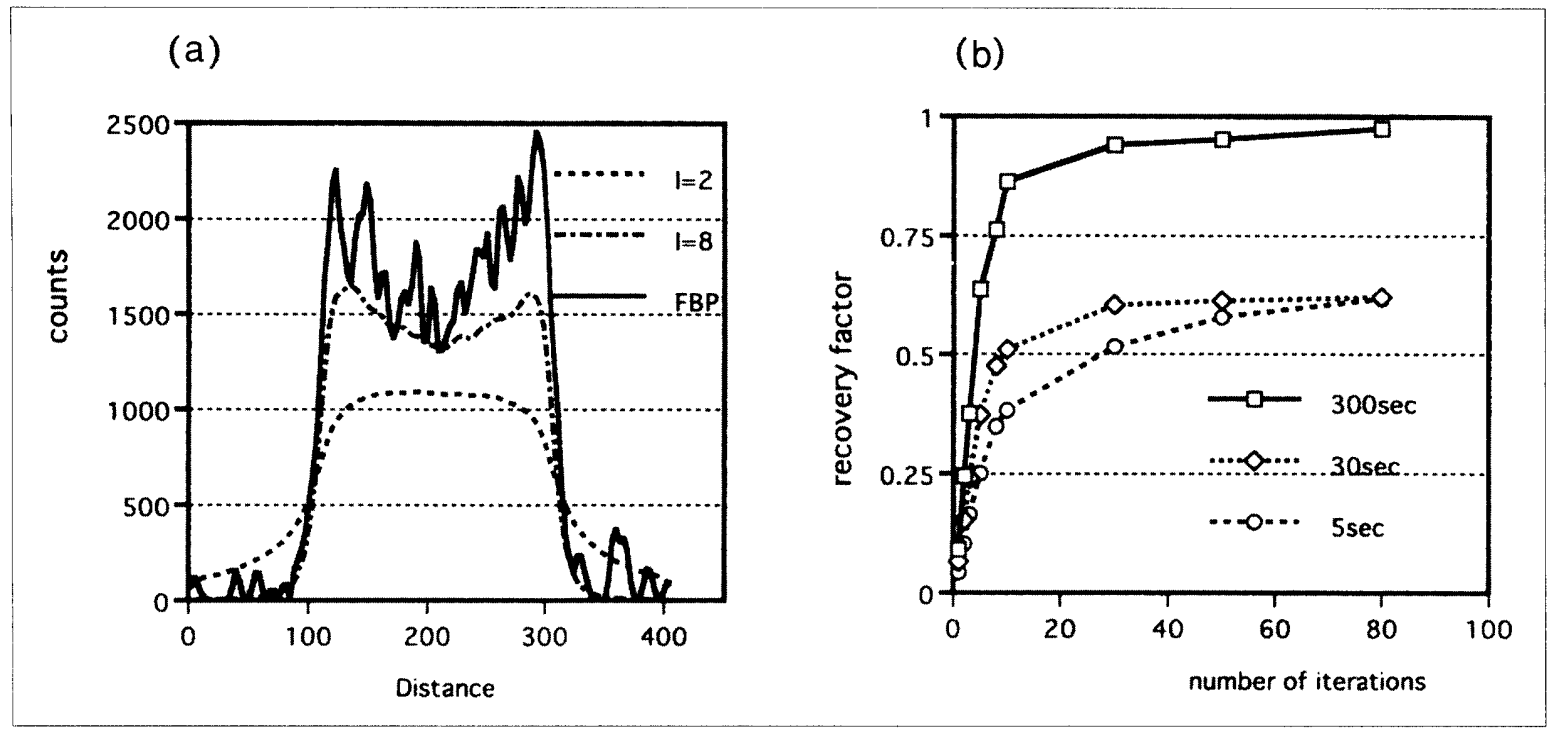

Fig. 4 (a) Profile curves for the uniform SPECT images (FBP reconstruction and ML-EM reconstruction). (b) Evaluation of edge recovery of images for iterations.

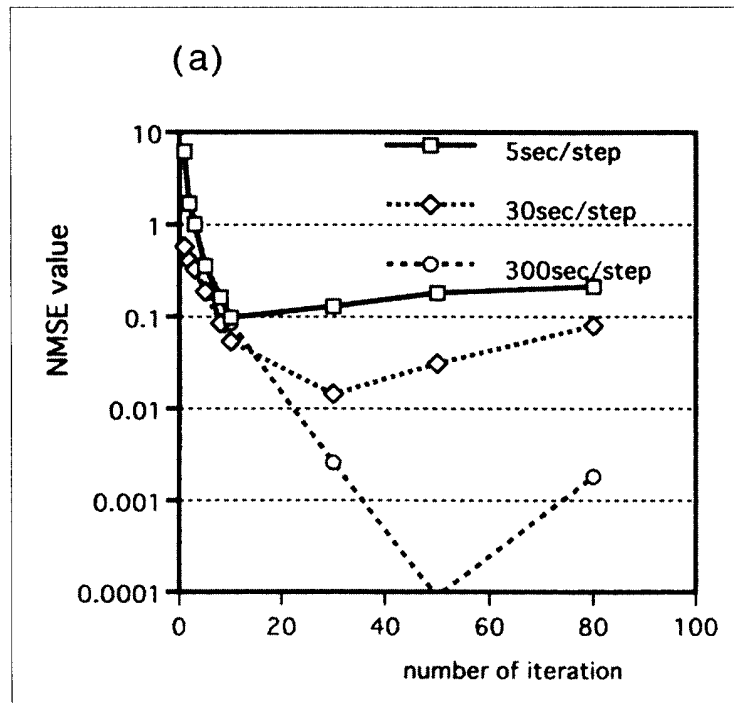

(b)

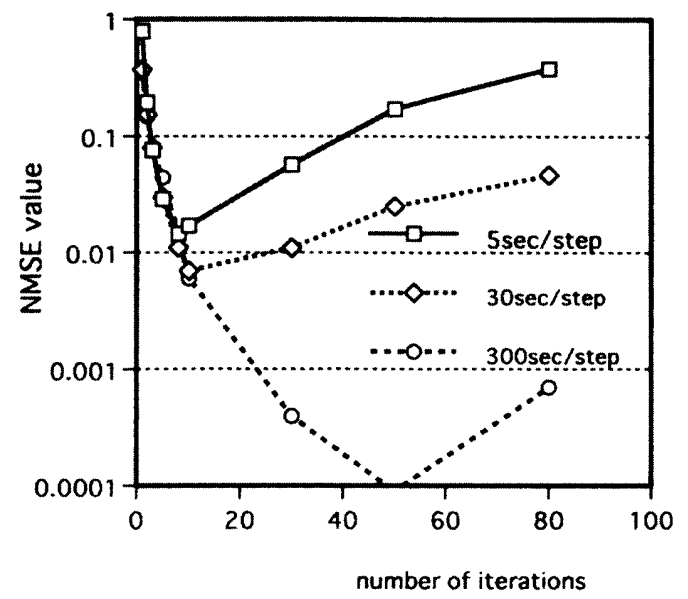

Fig. 5 Comparison of the optimal iteration for different acquisition times in the uniform cylinder (b) and hot $\operatorname{rod}(a)$ phantom SPECT images.

\section{3. 考 察}

ML-EM逐次近似画像再構成法での基礎的検傠とし て最適な逐次回数を収集時間を変化させて検討を行っ た。評価は画像の基本特性である分解能 (FWHM, FWTM), 統計雑音(RMSU) 拉よび画像エッジ部の回 復 $(\mathrm{RC})$ として単一的に評価し，画像全体の総合評価 としてNMSE法より臨床デー夕に類似した条件下で総 合的に検討評価した。

Fig. 1 から，長時間収集の場合で低周波成分を多く 含む画像と高周波成分を多く含む画像との差を視覚的 に見ても逐次回数を変えることによって雑音の発散が 異なる。これは画像に含まれる周波数成分が異なると
逐次回数も变化すると考えられる。この結果はFig. 5 に示すNMSE法による定軖評価で明確に差が現れてい る.

分解能に関しては，逐次回数を10以上増加させても FWHM拉よ゙FWTMはあまり変化しなかった。この 理由としては，本来逐次近似的に画像を再構成してい るだけであり，分解能はそれ以外の因子(コリメー夕 や距離依存性)が大きく影響すると考えられる。しか し, Gilland ${ }^{10)}$ の報告によると，散乱線補正(DEWS 法)および吸収補正（TCT法）を行うと逐次回数50で30 \%改善したとの報告もある.Fig. $3 \mathrm{~d} の \Delta \mathrm{RMSU}$ 值の变 化においては, 短時間収集 $(5 \mathrm{sec} / \mathrm{step})$ の場合にその值 
の変動は大きく，哀時問収集 (300 sec/step)では30－50 の逐次回数でほぼ圳な分布を示している。この逐次 回数は，浦部ら”同坪笘のシミュレーションデー夕解 析での雑涪を5ー10\%付加させ，吸仪補正なしの場全 のデータと问じ傾问をホして抢り流者の妥当性が評体 できる。実際臨床時での收集洔间には制限があり， $30 \mathrm{sec} / \mathrm{step}$ 收集時でも統計雑音の変動は逐次回数 50で もまだ仪束していない。エッジ部分の问復性に扔いて は，解析的困像垀構成法であるFBP泣を基集とした $\mathrm{RC}$ 值で画像のエッジ部の評価を行ったが， $5 \mathrm{sec} /$ step，30sec/step収集時では0.7となり[回復が渥くれ， 完全な囘復は認められなかった。これは，統計雑音の 星が少ないとき(唇時開収集)では雑音の発散が抑えら れる倾向にあるが雑音の量が多い埸合 $(5 \mathrm{sec} / \mathrm{step}$, $30 \mathrm{sec} / \mathrm{step})$ では雑音の量の増加により緩やかに発散が 生じている゙๋なだと考えられる、画像全体の評価と してのNMSE法評価では，最適逐次问数は30sec/step に扔いは宫成波成分を含む画像では逐次回数30，低周 波成分を含吉再像では逐次回数 10 と逐次回数が異なっ た。また，收集時間が短い場合 $(5 \mathrm{sec} / \mathrm{step}) に$ に扔いても 间じ傾们を示した。この結果からML-EM画像再構成 法に扮ける逐次回数は，低周波成分では早く収束し， 婷周波成分では収束が遅くなる。そもそもML-EM再 構成法は全投影デー夕を用いて画素值の変更を行うも ので，雑音にはadditive algebraic reconstruction technique (AART)やmultiplicative ART(MART) はどに
比較して強いが，雑消が少ない場合には誤差の発散が 抑えられるものの雑点の最が多くなると発散が始まる といわれている。また，エッジの多い曲像(阔閟成 分を多く含む)は収束も逑いといわ机ている。この絬 果はその部分を如美に少したものである。逐次回数が 少なければ本来のコントラスト(例えば，灭白質と白 質比)が得られないし，多すぎれば雑音が発散するこ とになる。心臟，脳などにより標的藏器の持つ闌波数 成分が異なる12,13) といわれて扮り，周波数成分に見命 った最適な逐次问数を導き出す必要がある。今问の検 討は，吸收補正捛よび散乱線補正などを行っていない が，今後の課題としてそれぞれの補、汗による影響，两 像フィルタ, ML-EM泣の変法であるOSEM法でのサ ブセット数などを検討する必要性がある.

\section{4. 結 語}

FWHM，FWTM值は逐次回数が10以上で同じ值に なり，収集カウントと逐次回数とは大きな関係があり RMSU值で評価すると逐次回数50(300 sec/step)でほぼ 阔じ倠に收束した。ほかの收集条件では，逐次回数 50以上でもその值は収束しなかった。エッジの回復性 ではRC值は300 sec/stepでは1.0に近づいたが，30 sec/

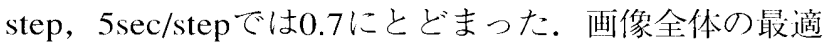
逐次回数は，高周波成分を多く含む画像では逐次回数 30，低周波成分を多く合む油像では逐次回数 10 とな り，画像に含まれる周波数成分により変化した。

\section{参考文献}

1) Sheep LA and Logan BF: Fourier reconstruction of a head section. IEEE Trans Nucl Sci, NS-21, 21-43, (1980).

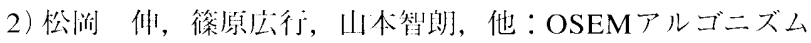

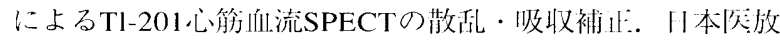
会誌，58，751-757，(1998）。

3）浦部洋史，㷊川悬子，尾川涉：SPECTに扮ける逐次近似 的伷像持構成法の比較。 Med Imag Tech, 18(1)，84-92, (2000).

4) Shepp LA and Vardi Y: Maximum likelihood reconstruction for emission tomography. IEEE Trans Med Imaging, MI-1, 113-122, (1982)

5) Lange $\mathrm{K}$ and Carson R: EM reconstruction tomography. J Comput Assist Tomogr, 8, 306-316, (1984).

6) Hurwitz Jr H: Entropy reduction in Bayesian analysis of measurements. Phy Rev A, 12, 698-706, (1975).

7) Lange K, Bahn M, and Little R: A theoretical study of some maximum likelihood algorithms for emission and transmission tomography. IEEE Trans Med Imaging, 6, 106-114, (1987).
8) 尾川浩一：OS-EMによる曲像再構成。放射線欻受物理, (3), 184-191, (1999).

9) Hudson HM and Larkin RS: Accelerated image reconstruction using ordered subsets of projection data. IEEE Trans Med Imaging, MI-13, 601-609, (1994)

10) Gilland DR, Jaszczak RJ, Wang H., et al.: A 3D model of nonuniform attenuation and detector response for efficient iterative reconstruction in SPECT. Phys Med Biol, 39, 547-561, (1994).

11) Murayama H, Tanaka E, and Nohara N: Comparative studies on various iterative image reconstruction algorithm for emission tomography. Med Imag Tech, 7, 315-333, (1989).

12) Ohnishi H. Ota T, Takada M, et al.: Two optimal prefilter cut-off frequencies needed for SPECT images of myocardial perfusion in a one-day protocol. J Nucl Med Technol, 25(4), 256-260, (1997).

13) 大西英雄：SPECT丒像の周波数解析。日放技学望，54 (10), 1247-1252, (1998). 


\section{図表の説明}

Fig. 1 收集時間拈よび逐次回数での隄性断面像および均一断面像の比較.

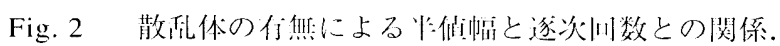

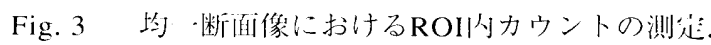
(a) ROIMO惨力ウント

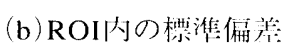
(c) RMSU佔:
(d) RMSU仙の変化摔

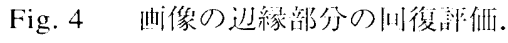

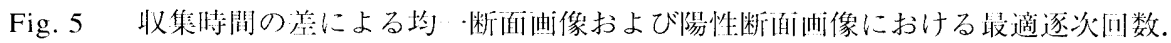

